\title{
Community Tourism Development in Viet Hai Commune (Cat Ba, Hai Phong City, Viet Nam) Under the Green Economy Model
}

\author{
Tran Van Phuong ${ }^{1}$, Le Xuan Sinh ${ }^{2}$, Le Duc Cuong 2 , Đang Cong Xuong ${ }^{3} \&$ Bui Thi Minh $\mathrm{Ha}^{4}$ \\ ${ }^{1}$ Natural resourse and Environment Department, Hai Phong, Viet Nam \\ ${ }^{2}$ Institute of Marine Environment and Resources (VAST), Hai Phong, Viet Nam \\ ${ }^{3}$ VietNam Maritime University, Viet Nam \\ ${ }^{4}$ University of Social Sciences and Humanities (USSH), HCMC, Viet Nam \\ Correspondence: Tran Van Phuong, Natural resourse and Environment Department, Hai Phong, 275, Lach Tray \\ street, Ngo Quyen district, Hai Phong city, Viet Nam. Tel: +84-912-123-842. E-mail: \\ tranvanphuong@haiphong.gov.vn
}

Received: March 24, 2020

Accepted: April 11, 2020

Online Published: May 5, 2020

doi:10.5539/enrr.v10n2p43

URL: https://doi.org/10.5539/enrr.v10n2p43

\begin{abstract}
The study of community tourism development based on green economy model is the focus of this paper. The research is implemented in Viet Hai - a commune of Cat Hai island district, Hai Phong city, Vietnam. In order to evaluate, select and develop this model in the locality, a number of research methods have been applied such as: Method of seminars, expert consult, group system of sampling methods, fertilizer analyzing laboratories and methods of interviewing and collecting socio-economic data. The research outcome is given that, the community tourism based on green economy is a type of economic model that contributes not only on the local socio-economic development, but also surmounting the seasonal tourism situation, and maximizing the region's potential and strengths. The model chosen was the communitys based tourism model, with the participation of $1 / 3$ of households in Viet Hai commune. The model has a management board with applicable rules and regulations to objects such as households, tourism operators and Viet Hai visitors. The model has been oriented towards exploiting the landscape values associated with environmental protection programs, especially towards the point-based community tourism model of Cat Ba district - which say "no" to single-use plastic products. This tourism model has created the tourism products that are different from the existing models in Cat Ba (Hai Phong), creating channels to link with tourists to attract more visitors to Viet Hai increasingly to the year.
\end{abstract}

Keywords: Viet Hai Commune, Community Based Tourism Model, Green Economy Model

\section{Introduction}

\subsection{Introduce the Problem}

Tourism in the green economy refers to tourism activities that can be maintained, or sustained, indefinitely in their social, economic, cultural, and environmental contexts: "sustainable tourism". Sustainable tourism is tourism that takes full account of current and future economic, social and environmental impacts, addressing the needs of visitors, the industry, the environment and host communities. It is not a special form of tourism; rather, all forms of tourism may strive to be more sustainable (UNWTO, 2012). There is a growing focus on tourism as a generator of FDI in developing countries. Tourism is a major priority of Investment Promotion Agencies (IPA) in many developing countries. In this regard, the case of Costa Rica is illustrated as foreign investment in the tourism sector represented 17\% of total FDI inflows in 2009 and 13\% on average for 2000-2009 (UNCTAD, 2009). The Pacific member countries have a combined population of about 10 million people, spread across vast sea areas, made up of hundreds of islands, and scattered over an area equivalent to $1 / 3$ of the globe's surface. The models of ecotourism and community-based tourisms are the solutions to greening this area. These models use local products, preferably use clean energy, and effectively manage waste. At a small scale, community-based ecological models have begun to be implemented in a number of places. Tourism is an important and potential economic sector of this region, with some countries such as Palau and Cook Islands, tourism accounting for 50\% of GDP (UNESCAP, 2012).

Viet Hai is a commune of Cat Hai island district, Hai Phong city, Vietnam. The commune is located in the eastern part of Cat Ba Island, the third largest island in Vietnam. On the main island, Viet Hai borders with Gia Luan and 
Tran Chau communes to the west, and Cat Ba town to the South. Viet Hai commune has a planned boundary with a total natural area of $86.25 \mathrm{~km}^{2}$ (People's Committee of Viet Hai commune, 2018), of which the land area managed by the commune is 141 hectares with a population of 270 people, 88 households, and a density of 2.5 people. $/ \mathrm{km}^{2}$. Here, the economy has underdeveloped. Last time, there was no market, even food sources have mainly been purchased from the mainland or self-sufficient. Agricultural, forestry and aquaculture production are of a small and spontaneous nature and is increasingly narrowed.

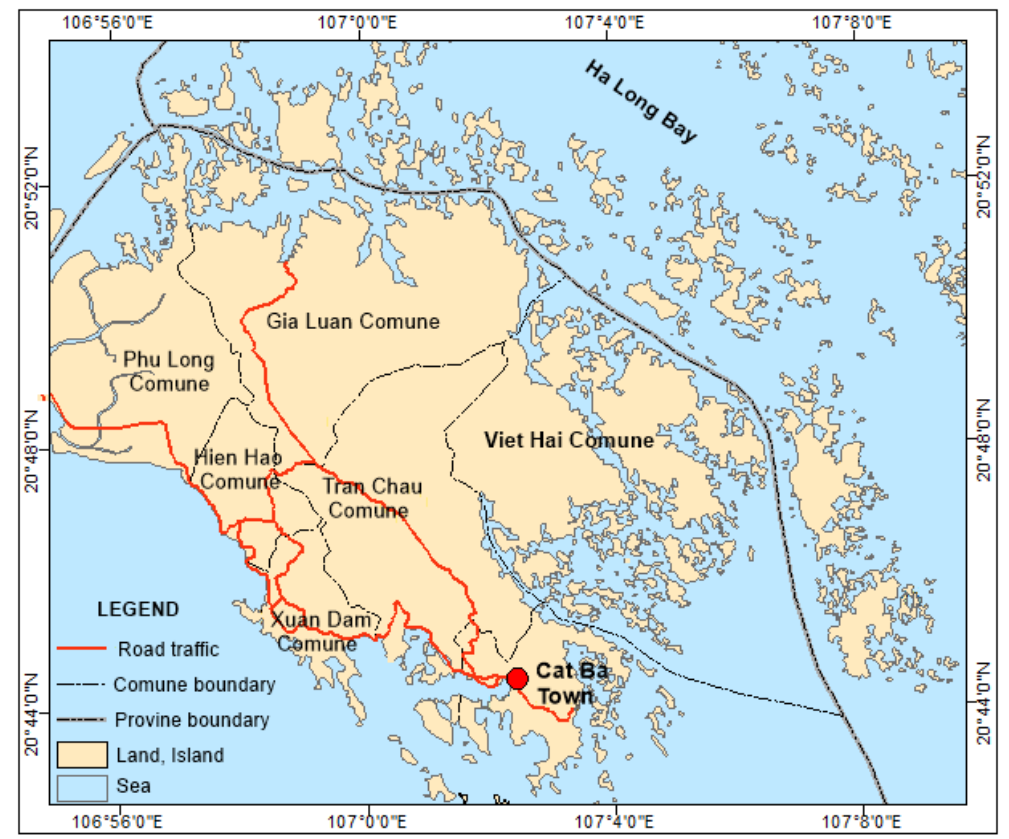

Figure 1. Viet Hai commune, Cát Hải island province, Hải Phòng (Source: KC.08.09/16-20, 2018)

The community based tourism model is a type of tourism that helps the local socio-economic development, overcoming the seasonal tourism situation, maximizing the region's potential and strengths. The economic development orientation in Viet Hai commune follows the commune based tourism model under the direction of the People's Council of Cat Hai district (Hai Phong city, Viet Nam), which was determined in 2016. The community based tourism model develops according to the the direction of the green economy ensures harmonious economic development factors, which attracts free laborers to convert to tourism to improve the quality of life while it still ensures the environmental protection. Based on analysed factors in Vietnam and factors in the world, this study proposes a green economy oriented community-based tourism model in Viet Hai commune.

\section{Documents and Methods}

\subsection{Documents}

Resources and data collected from field trips and thematic reports from the research project KC.08.09/16-20: "Study on building a green economy model for some typical island communes along the Vietnamese coast".

\subsection{Method}

Viet Hai commune is an island commune located on Cat $\mathrm{Ba}$ island, but it is isolated on culture, society and self-sufficient economy, mainly exploiting natural resources. The population here is small number with blood relation, the cultural level is not high, so it is embarrassing to build an appropriate economic model.

In this study, the selected island commune as a research site to build the first green-tourism community-based tourism model in Vietnam because island communes are in need of development orientation to help people attaining sustainable livelihoods replaced for the exhausted exploitation of natural resources. With the system of Vietnamese methods and prestigious organizations (UNEP, UNWTO, UNCTAD, UNESCAP) based on legal and policies, surveyed data in Viet Hai commune are as follows:

- Methods of seminars and expert consult are applied and analyzed to assess data, build information systems and summarize data. 
- Method groups including sample collection and laboratory analysis are applied to collect air samples, surface water samples, soil samples, seawater samples, soil and marine sediments based on VietNamese standards.

- QCVN 05:2013/BTNMT: National Technical Regulation on Ambient Air Quality

- QCVN 10-MT:2015/BTNMT: National technical regulation on marine water quality

- QCVN 09-MT:2015/BTNMT: National technical regulation on ground water quality

- QCVN 08-MT:2015/BTNMT: National technical regulation on surface water quality

- QCVN 43:2017/BTNMT: National Technical Regulation on Sediment Quality

- Methods of interview, survey by questionnaire are applied to collect socio-economic data, design sample forms for socio-economic evaluation in Viet Hai.

- Data processing method: Using statistical software and Excel 2017 data processing.

\section{Results}

\subsection{Tourist Model}

After survey and research on the environmental and socio-economic situation in Viet Hai commune, we found that, this commune has faced economic underdevelopment and the risk of exploited natural environment. In order to reach the sustainable development, it is necessary to orient the development according to the green economy model on the basis of environmental friendly production and service industries; preserve and develop forests to protect biodiversity and the ecological environment; develop fisheries economy in the direction of approaching the modern aquaculture technology process and prioritize the development of eco-tourism, considering this as a driving force for other economic sectors, creating a career restructure, and increase income for residential community on the island. (Figure 2).

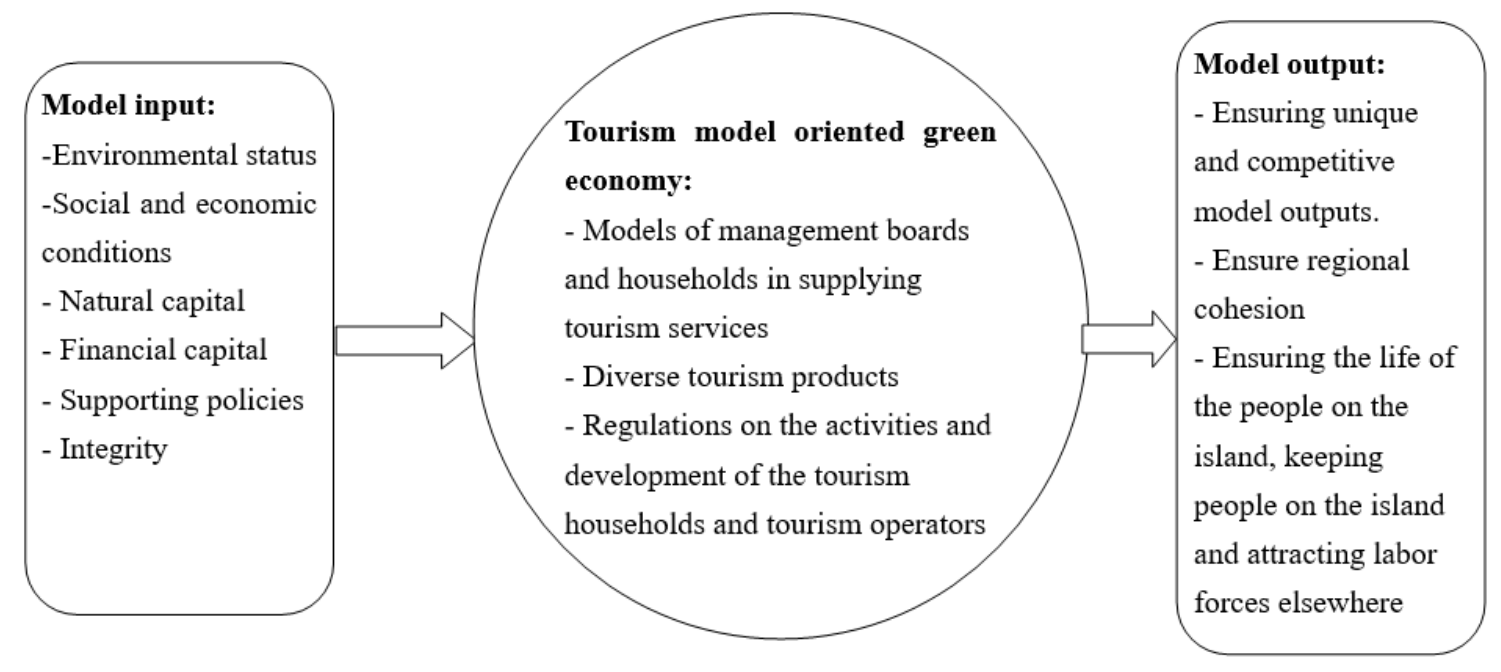

Figure 2. Tourism model based on green economy is applied in Viet Hai commune

(Source: KC.08.09/16-20, 2018)

\subsection{Analysis of Tourism Model Inputs}

\section{a. Social Condition}

There are approximately 78 households living in Viet Hai commune currently, with the main business lines including: tourism services, agriculture, aquaculture, forestry and fishery exploitation. The population of 200 people with main occupations is focused on tourism, agriculture and natural exploitation services. The number of working-age population accounts for $60 \%$. Residents here are hard-working, honest, and desire to develop tourism to increase income and change their lives. 
Table 1. Rate of labor distribution of Viet Hai commune

\begin{tabular}{|c|c|c|c|}
\hline TT & Content & Status in 2018 & Forcast for 2020 \\
\hline \multirow[t]{2}{*}{ I } & Population in working age (people) & 167 & 234 \\
\hline & Percentage of population & 57,7 & 60 \\
\hline II & Career division & & \\
\hline \multirow[t]{2}{*}{2.1} & Agricultural labor (person) & 75 & 70 \\
\hline & Percentage of employees working & 46 & 29,7 \\
\hline \multirow[t]{2}{*}{2.2} & Non-agricultural labor (people) & 92 & 163 \\
\hline & Percentage of employees working & 54 & 70,3 \\
\hline
\end{tabular}

Sources: KC.08.09/16-20, 2018

\section{b. Environmental Status}

According data of the survey on december 2017, samples of the air environment, surface water, sea water, soil and marine sediments all showed results within the permissible limits of the Vietnam standard allowed to prove the environment of Viet Hai commune are quite clean and safe (Le Van Nam et al., 2019 \& Tran Van Phuong et al., 2019). Solid waste is being collected, classified and treated quite well such as a collection system, enhance local people's awarenessand on landfills.

\section{c. The Natural Capital}

The most outstanding natural capital of Viet Hai commune is an island commune with beautiful natural scenery located in Cat Ba National Park. The area under the management of the commune is located in Lan Ha Bay, with a system of tidal flats, sandbanks and natural coral areas.

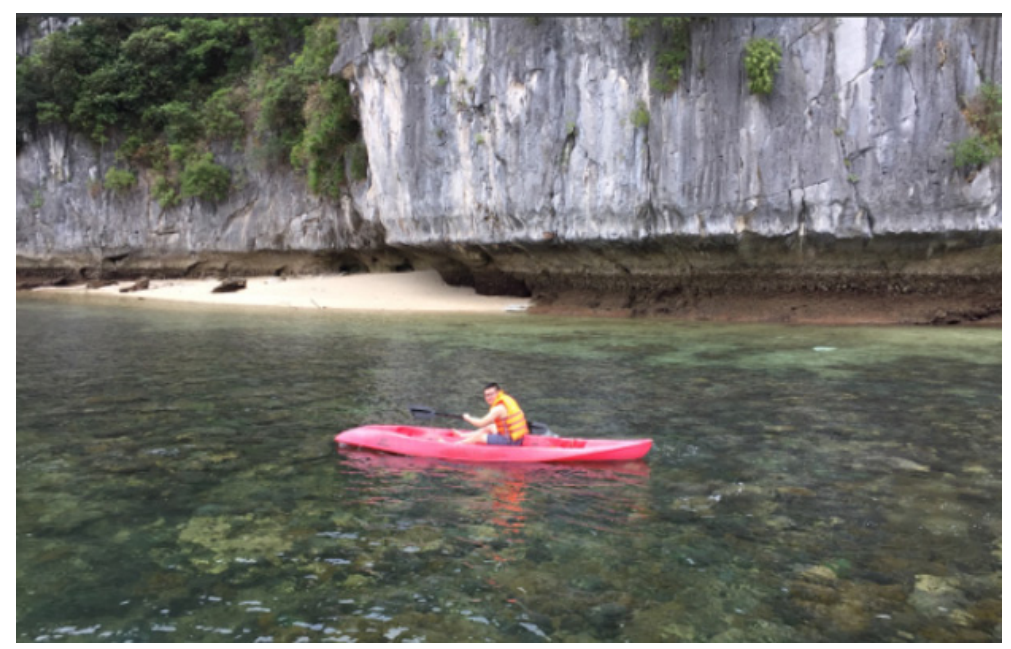

Figure 3. The white sands at Van Boi, Cat Ba island, Cat Hai district (Hai Phong city)

Sources: KC.08.09/16-20, 2018

The island commune - Viet Hai is the southeastern grillage of Cat Ba Island - Cat Hai district. Located in the core of Cat Ba National Park (the world biosphere reserve) with characteristics such as majestic mountains, charming mountains, many fertile valleys and streams flowing years round. Viet Hai has a diverse array of forest, marine and rare flora. Biodiversity is a prominent feature of Viet Hai for developing tourism resources (Le Xuan Sinh et al., 2019).

The Figure 3 expresses the white sands at Van Boi (Cat Ba island) - here visitors can take both bathing and watching the coral. It is one of diverse natural ecosystem in Viet Hai. Natural ecosystems include forests, mangroves and scrub - grasslands. Other human ecosystems include only agricultural ecosystems (wet rice, residential areas). Although it is not as rich as the fauna in the special-use forests on the mainland, the animal population here still has up to 20 species of mammals; 69 species of birds; 20 reptiles and amphibians. The commune's marine ecosystems are potential, valuable natural capital. Intertidal ecosystems are typically sandy tidal flats, rocky tidal flats, mudflats. Especially, sandy tidal flats are concentrated in small islands, around Lan Ha 
Cat Ba Bay such as Van Boi, Ba Trai Dao, Hang Trai - Dau Be area. In addition, the coral ecosystem in most concave arches of rocky islands (usually with sandbanks distributed above) in the study area has corals distributed at depths 3, 6, 9 and 11 meters (Le Xuan Sinh et al., 2019).

\section{d. Conection}

In order to develop tourism, the conditions for traveling from the mainland to the island commune must be diversified, but currently, it is mainly used by waterways and mountain trails from Cat Ba National Park to Viet Hai. The connection to the main land is weak, depended on weather conditions, even it must pay the high travel costs. Hence, this is a challenge for tourism development in Viet Hai commune.

Table 2. Travel time for transportation from Cat Ba to Viet Hai and sightseeing facilities in Viet Hai

\begin{tabular}{clll}
\hline No & Means before implementing the project & Travel time & Note \\
\hline 1 & The boat is supported by the state & 45 minutes & Being subsidized by the government, there are 02 trips in a day \\
2 & Nan boat to Cai Beo wharf & 60 minutes & Only boats in Cat Ba \\
3 & Small boat & 40 minutes & Vehicles run on a trip between Cat Ba and Viet Hai. \\
4 & Electric car & 10 minutes & $01 \mathrm{PC}$ \\
5 & Bicycle & 15 minutes & $30 \mathrm{PC}$ \\
\hline & Means after implementing the topic & Travel time & \\
\hline 6 & Cano & 12 minutes & Ensure continuous operation, can travel 24 / 24h \\
7 & Electric car & 10 minutes & $13 \mathrm{PCs}$ \\
8 & Bicycle & 15 minutes & $300 \mathrm{PCs}$ \\
9 & Motorcycles driving in the forest & 10 minutes & $03 \mathrm{PCs}$ \\
\hline
\end{tabular}

Source: our research in three communes

\section{e. Financial Capital}

The result of the household survey of Viet Hai commune showed that, the living standard and income are low. There are only 5 households with a developed economic life because of financial support from the outside such as foreign exchange, shares or money sent by their children working away from home. Part of the capital of the people comes from selling real estate to raise capital $(60 \%)$, so that they get enough money to build homestay-oriented tourism models. However, the construction cost in Viet Hai is quite high due to the cost of transportation of materials to the island commune, details are shown in the table below:

Table 3. The table comparing prices of raw materials between the mainland and Viet Hai commune (2019)

\begin{tabular}{|c|c|c|c|}
\hline STT & Material & Purchase price in main land (unit price: thousand d) & $\begin{array}{c}\text { Purchase price in Viet Hai } \\
\text { (unit price: thousand đ) }\end{array}$ \\
\hline 1 & Brick (pellet) & 1,1 & 2,2 \\
\hline 2 & Cement marks 200 (sack 50 kg) & 75 & 200 \\
\hline 3 & Vietnam-Australia Steel 10 (stick) & 100 & 150 \\
\hline 4 & Vietnam-Australia Steel 12 (stick) & 200 & 250 \\
\hline 5 & Sand $\left(\mathrm{m}^{3}\right)$ & 310 & 500 \\
\hline 6 & corrugated iron roof $\left(\mathrm{m}^{2}\right)$ & 340 & 600 \\
\hline 7 & Stone $\left(\mathrm{m}^{3}\right)$ & 300 & 450 \\
\hline
\end{tabular}

Source: KC.08.09/16-20, 2019

By comparison, the difference in unit price coefficient varies from 1.5 to 2.2 times, it shows that building a synchronous homestay model in Viet Hai requires high cost. The survey's result showed that in total 60 households, 45 households (accounting for 75\%) were those with average income, sufficient income to cover their livelihood. The rest $25 \%$ were freelance labour and had depended on the season so the internal capital was weak. Therefore, in order to reach the community based tourism models with homestays in the standard model, households need to attract investors from outside of the community to do business, to contribute or share real capital. 


\subsection{Tourism Model in Viet Hai Commune}

Orientation to develop tourism based on the Community-based tourism model is a type of tourism that promotes the local socio-economic development, contributes to overcoming the seasonal tourism situation, maximizing the potential and strengths of the region. Establishing a Community Tourism Management Board according to the diagram in Figure 4.

a. Community Tourism Management Board of Commune

- Participants: Representatives of households doing tourism, Representatives of the community, Local tourism enterprises, local authorities.

- Function: Implementing the right to coordinate all tourism activities taking place in Viet Hai commune area. The Management Board will be representative for community in promoting tourism, seeking funding ... to develop tourism in the locality.

The relationships among components is determined as follows:

- Between the model management board and the commune People's Committee is the management coordination relationship, with an appropriate benefit sharing ratio.

- Between the Management Board and households doing tourism, tourism businesses are business cooperation relations. Tourism management board will design, build, manage tourism products, and through households, local businesses, and local labor force selling tourist products, at the same time they implement the right to supervise and manage the business of this component as prescribed.

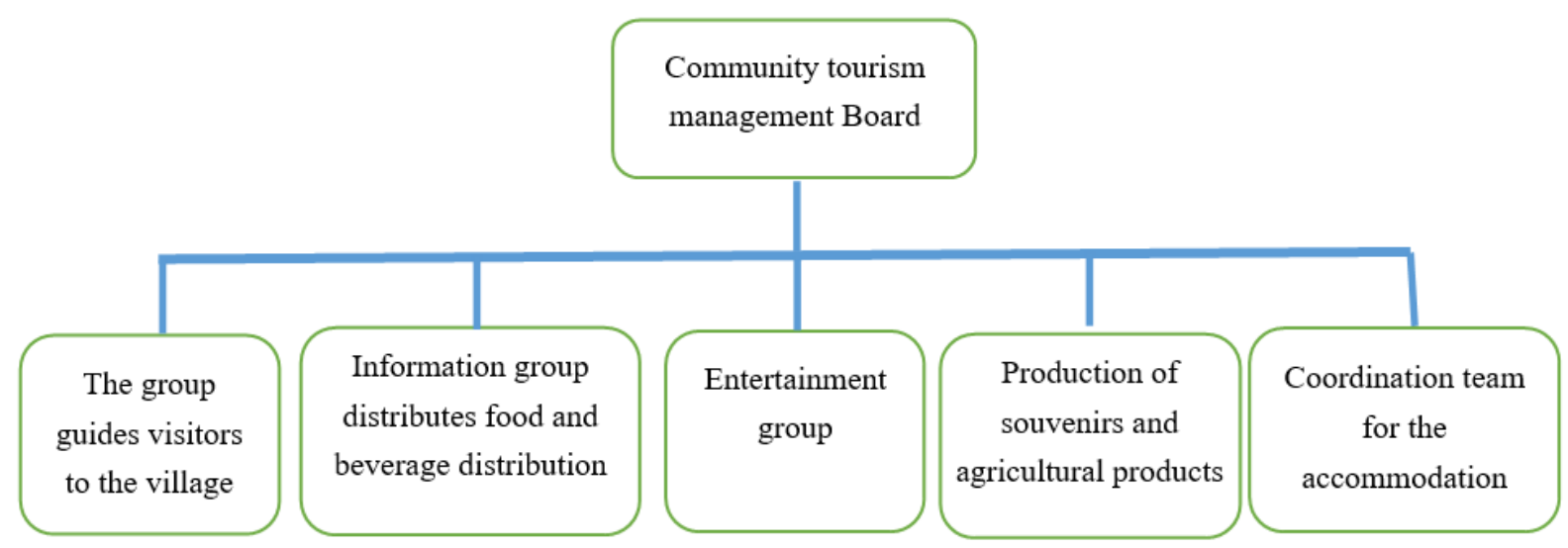

Figure 4. Organizational chart of the model of communitys based tourism activities in Viet Hai commune

- There is a cooperative and competitive connection between business households, businesses, and local labor as prescribed.

- The National Fatherland Front in Commune is the unit that oversees the activities of the Community Tourism Model Management Board, and receives remuneration from the Model Management Board.

- General financial management, revenue and expenditure from tourism activities. Establish and manage a register of cash receipts, payments, community bank accounts, invoices and documents.

- Establishing and implementing a rotating mechanism for equitable tourism benefit sharing in the community.

- Managing tourism service providers in the commune

- Contracts and tour bookings, sightseeing services from businesses

+ Guide group for visiting village: Set up a tour guide book, visit landmarks in Viet Hai village. Train local tour guides, require tours to be combined with local people or rented separately. The group leader regulates the tours in the village. Participating forces: Young people and people meet the requirements of communication and health.

+ Information group in Food distribution: Establishing a restaurant network, the number of customers to support and share large groups of guests. Create a model of restaurants operating in a variety of typical dishes, Vietnamese cuisine, Asian and European cuisine. Create a restaurant business support network when a large number of customers order food, assistant cooks, cooks, and waiters. Creating a network of shuttle services for customers, 
goods and food transportation. Participating force: List of households with restaurants, local people with good health and skills.

+ Entertainment group: Set up a music group to perform music and dance performances for visitors during the day and overnight. Create jobs for local people to participate in commune cultural and art activities. Participating forces: List of commune art teams, teenagers and communal cultural committees.

+ Production group of souvenirs and agricultural products: The group concentrates on locally grown and processed items such as products from Hibiscus, such as fresh flowers, processed products (wine, tea, jam), precious wine, agricultural products. Exploiting values from local products for tourism, improving the value of the products. Participating force: Members of farmer's union, local people.

+ Coordinating groups of rooms: The group focuses on regulating tourists to rooms evenly, ensuring the number of tourists is spread evenly through households who provide community tourism services. Periodic monitoring of the quality of the accommodation equipment. Participating force: Business households providing homestay services.

\section{b. The Operating Regulations}

+ Establish the regulations of local communitys based tourism activities: 05 regulation groups were developed with the participation of members in local community tourism with the purpose to regulate the management and organization of the local tourism activities to ensure equity in the rights and obligations of stakeholders.

+ Establishing the rules of the CBT model: The Community Tourism Management Board develops the rules on community tourism activities and recommends all members to participate in community tourism activities, tourists and tour operators follow with 10 rules:

1. Ensuring security and safety for tourists during their visit.

2. Reasonable and uniform service and goods prices. Post and sell goods at the prescribed prices, absolutely do not cheat tourists and travel companies.

3. Do not ask for anything from your guests such as money, candy and supplies.

4. Keep the environment clean in the commune and preserve well the facilities for tourism.

5. No harm to plants and animals in the area.

6. Encourage and supervise tour operators and tourists to comply with the community tourism regulations.

7. Immediately notify the communal tourism management board if the tour operator or tourist violates the community tourism regulations.

8. Respect and strictly follow the rules issued by the Management Board.

9. Dress politely in accordance with traditional customs when tourists come to visit.

10. Respect the privacy of guests when staying overnight.

These rules will help tourists visiting Viet Hai commune to be comfortable, respected and shared with their friends.

c. Spatial Planning in the Commune for Functional Zoning

By using technologies such as GIS or graphical software, create spatial planning maps on island communes to specify areas of economic sectors, scale and characteristics. This construction depends on inputs such as: natural and social conditions, mechanisms, policies, economic development orientation of Viet Hai commune under Decision 1048 / QD-TTg signed on August 21 ${ }^{\text {th }}, 2019$ on the issuance of evaluation criteria set for each commune. Viet Hai commune is oriented to develop according to the model of community-based tourism, so the spatial planning to ensure the balanced development between economy and environment. 


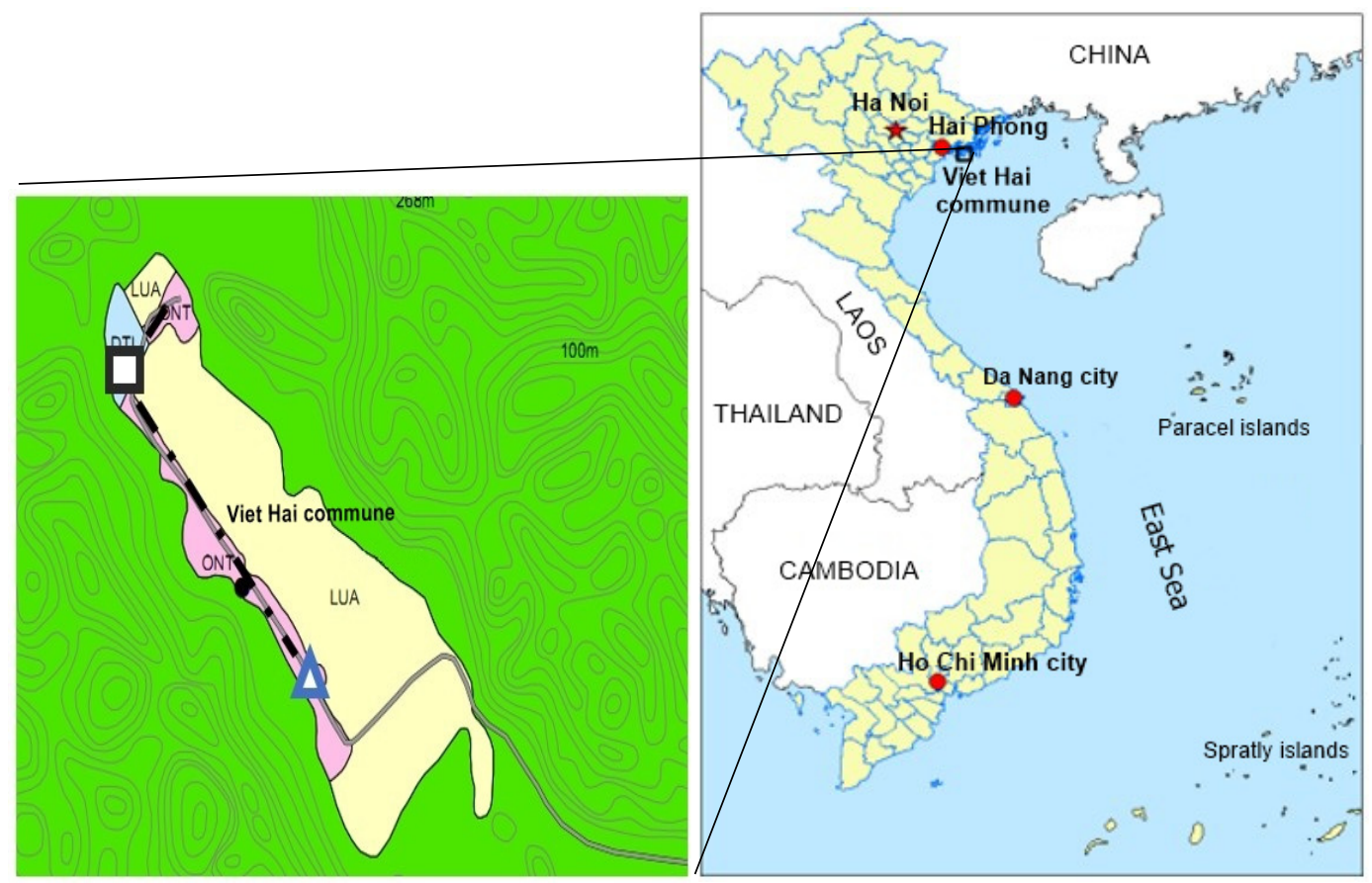

Figure 5. Spatial planning at the commune for functional zoning of Viet Hai commune

In which:

+ LUA: The area of agricultural land used in part for the model of growing vegetables in a greenhouse (red circle area), taro growing in green circle area, along both sides of the road from the entrance gate to the greenhouse of periwinkle flowers (red line). Planting periwinkle garden and rose tree in green ellipse area.

+ ONT: Rural land area, using a small garden of $100 \mathrm{~m} 2$, planted with periwinkle, Hibiscus sabdariffa L. and some other flowers (Triangle). The model of successful flower-growing model, encouraging the islanders to bring their seedlings to home gardening, contributes to the spread of flower plants in Viet Hai. In addition, a small area of residential land is used to raise horses for sightseeing and traveling around the island (Square area). In households, planting paper flower gates as a highlight to attract tourists (dashed line).

+ DTL: Land area for freshwater lakes

\section{d. Oriented Development}

+ The oriented goal is the employment increase of local people involved in Community based tourism (CBT), visitor arrivals, and revenue.

+ Solutions and training plans to improve the capacity of the CBT team.

+ Building tour program for tourists.

+ The community based tourism development orientation incorporates green solutions towards sustainable tourism development.

- Viet Hai commune oriented not to use plastic bags.

- Tourism business households must know how to classify and handle rubbish thoroughly.

- Use environmental-friendly vehicles such as electric vehicles, devices with renewable energy such as solar water heaters, solar batteries to illuminate the road.

\subsection{Assessing the Factors for Developing Communitys Based Tourism}

\section{a. Economic Factors}

In order to compete and attract tourists, the community based tourism model has a Management Board to manage and orient the community tourism development in Viet Hai commune with the following characteristics: 
- The means to help tourists travel smoothly, the short only 12 minutes for traveling from Cat Ba to Viet Hai, the service time is $24 / 24 \mathrm{~h}$ (Table 2). Bike tours to the village are typical tourist products that are both environmental friendly and improves the health of visitors.

- The homestay model is an eco-designed two-story house designed with concrete floors painted with fake wood, the model is both unique but does not use wood materials like other places. The model of house can resist flooding when natural disasters happen because this is a valley so it is affected by flooding in the rainy season.

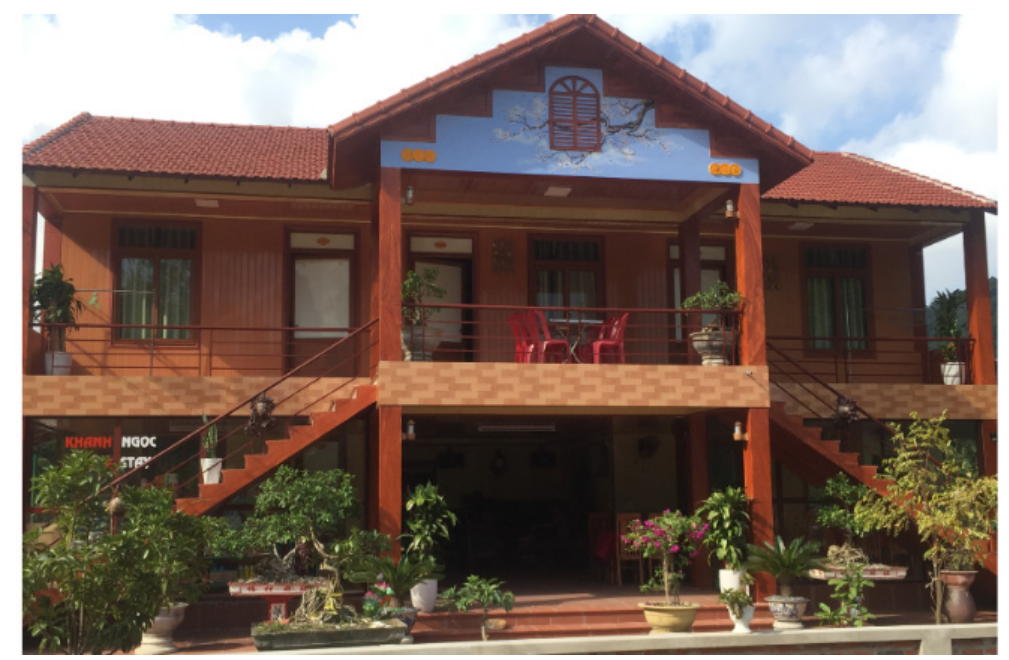

Figure 6. Model of homestay house in Viet Hai, home value of 65.000 U.S. dollar (source:KC.08.09/16-20, 2018)

- The tourism model has many products and tours based on ecological landscape to help visitors experienced with 16 points, tours in 2 days and 1 night.

- In the model, flower growing area was planned and tested, this is a tourist attraction point. Especially, Hibiscus sabdariffa L. is a good solution, because when they are planted into a concentrated area, creating not only a landscape for tourism but also a medicinal material to be able to sell fresh flowers, other finished products such as leaves, syrup, wine, soft drinks, seed oil extract (Hoang Van Tuyen et al., 2019). Rose Hibiscus sabdariffa L. belongs to hibiscus family, easy to adapt to arid, poor nutritious soils. The product of Hibiscus sabdariffa L. is diversified for processing, has a market price and is a good solution for a model of tourism-agriculture conversion and a model of climate-adaptive crop. The commune is supported by state projects to create landscapes on the roads from Viet Hai wharf to the commune, such as planting flowers on both sides of the road, creating a $4 \mathrm{~km}$ hibiscus fence along both sides of the road.

- The model has been supported by media marketing plans through THP, VTV1, VTV4 channels, etc., creating Viet Hai tour pages on Facebook, creating tour brochures in multiple languages to promote tourism. The number of visitors increased from 100 visitors / day to 300 people / day visiting the commune.

\section{b. Environmental Model}

- Tourism model management boards and tourism participating households have been trained and have accessed to information on waste classification and environmental materials. All households in the commune were trained to become a pilot model of Cat Hai district on the program "No one-time use of nylon and plastic bags" chaired by Cat Hai district, supported by the project KC.08.09/16 -20.

- Forest protection measures have been closely coordinated by Cat Ba National Park's forest protection agency and commune authorities, border guards and local people to protect forests and conserve natural landscape values in Commune.

- Using solar battery devices to light the way (24 columns along the way), 03 solar vessels at tourist households help save service costs, this is a factor to evaluate the criteria of reducing carbon emissions

Sort waste at the source thoroughly, have an organic compost model to serve the organic agriculture model for individual households and farmer associations in Viet Hai commune. Implement a process of hygienic landfill in the communal landfill such as no manual burning, spraying of insecticidal preparations, landfilling after burial is high enough. 
- The model of visiting coral at the point of corals in the commune such as Van Boi and Ba Trai Dao by glass-bottom boat helps visitors to experience new but avoid directly impacting on coral ecosystems.

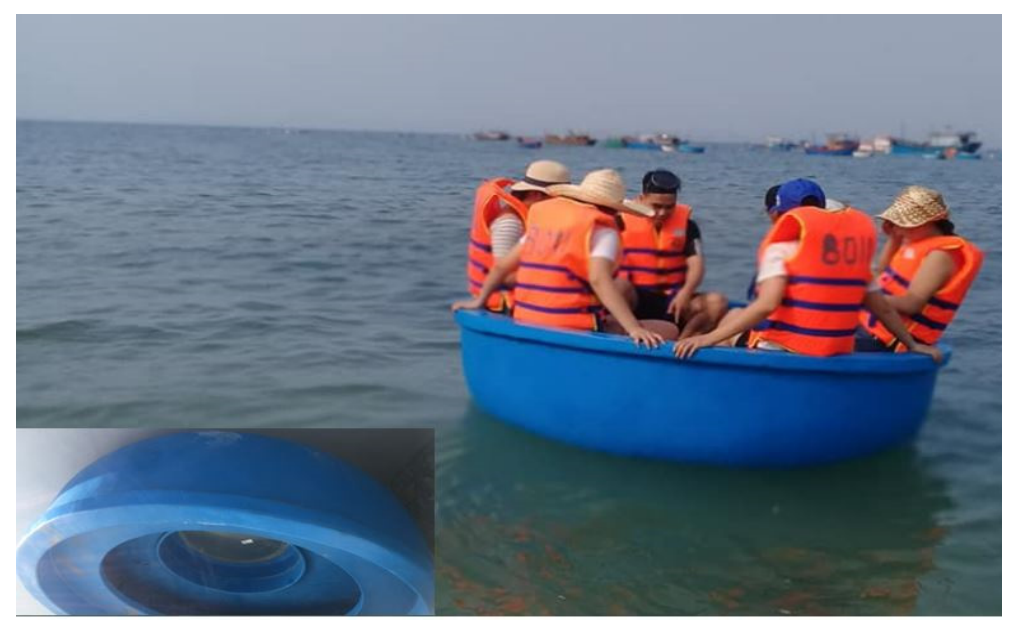

Figure 7. Glass-bottom boat to protect coral reef in Viet Hai community

(source:KC.08.09/16-20, 2018)

\section{c. Creating Livelihoods and Improving the Lives of Viet Hai People}

- The model of the implementation topic helps the tourism model increasingly create livelihoods and improve people's lives in Viet Hai. The model of the implementation project helps tourism development in the commune through the following Table:

Table 4. Growth data of Viet Hai commune tourism model

\begin{tabular}{lccc}
\hline \multicolumn{1}{c}{ Parameter } & Not involved in the project (11/2016) & Survey 12/2017 & Survey 6/2019 \\
\hline Number of households doing tourism (households) & 5 & 7 & 19 \\
Accommodations (rooms) & 8 & 14 & 41 \\
Electric cars (vehicle) & 2 & 5 & 13 \\
Cano (piece) & 0 & 0 & 3 \\
Number of guests (people) / day & 50 & 150 & 300 \\
Annual income (million VND) & -- & 48 & 96 \\
\hline
\end{tabular}

Source: KC08.09/16-20, 2019

The data show that the community-based tourism development model has attracted a labor force in Viet Hai commune from only 05 households (at the first time when the overall survey did) then has reached to 19 households, accounting for $30 \%$ of households in Viet Hai commune. Capacity to meet the number of guests staying with 41 rooms, an increase of 3 times compared to the time of the survey in December 2007 and 5 times higher than the time when the project was not implemented. The average annual income per capita doubles, from 48 million / year to 96 million / year, which demonstrates the effectiveness of the CBT model in Viet Hai commune.

\section{Discussion}

Community tourism was selected according to the development of a green economy model, with the participation of $1 / 3$ of households in Viet Hai commune. The model has a management board with rules and regulations applied to objects such as management boards, households, tour operators and Viet Hai visitors. The model is oriented towards exploiting the landscape values associated with environmental protection programs, especially towards the point-based community tourism model of Cat Hai district: "Saying no to single-use plastic". The tourism model has created products and tours that are different from the existing models in Cat Ba (Hai Phong), creating channels to link with tourists to attract more visitors to Viet Hai increasingly by years. The model created jobs for $1 / 3$ of workers in Viet Hai, attracting workers from agriculture and freelance labor to work in tourism. The income 
of Viet Hai people has doubled by travel services. The model of green-tourism based community will be a model for Vietnam's coastal island communes towards sustainable development.

\section{Acknowledgments}

The authors of this study acknowledged the research entitled "Research on developing a model of Green economy for some typical island communes in Viet Nam coastal areas" - Reference no. KC.08.09/16-20 for providing us materials to conduct this study.

\section{Conflict of interests}

The authors declare that there is no conflict of interests regarding the publication of this paper.

\section{References}

Hoang, V. T., \& Le, X. S. (2019). The role of hibiscus sabdariffa Rose 1. in developing green economy in Viet Hai commune). Collection of National Science Forum 2019 "Marine biology and sustainable development", Hải Phòng, (8, 2019) (pp. 750-761).

Le, V. N., Le, X. S., \& Nguyen, X. S. (2019). Air quality index in some typical island communes on Vietnam's coast. Journal of Marine Science and Technology, 58, 76-80.

Le, X. S., Hoang, T. C., Bui, T. M. H., \& Tran, V. P. (2019). Evaluation of indirect and non-use value of marine ecosystems in Viet Hai commune (Cat Hai, Hai Phong). Journal of Environment, I(2009), 78-84.

People's Committee of Viet Hai commune. (2018). Explanation of the general planning for new rural construction of Viet Hai commune - Cat Hai district - Hai Phong period 2011-2015 orientation towards 2020. Planning report (pp. 1-20).

Tran, V. P., Le, X. S., \& Nguyen, V. B. (2019). Current situation of seawater quality in some coastal communes in Vietnam. Journal of Marine Science and Technology, 19(3A), 111-120.

UNCTAD. (2009). World Investment Report 2009: Transnational Corporations, Agricultural Production and Development. UNCTAD, UN, New York and Geneva.

UNESCAP. (2012). Green-Economy-in-a-Blue-World: Pacific Perspectives. United Nations publication. ISBN: 978-982-9141-01-9.

UNWTO. (2012). Tourism in the Green Economy - Background Report. UNWTO, Madrid.

\section{Copyrights}

Copyright for this article is retained by the author(s), with first publication rights granted to the journal.

This is an open-access article distributed under the terms and conditions of the Creative Commons Attribution license (http://creativecommons.org/licenses/by/4.0/). 